\title{
The effects of pension rights and retirement age on training participation: evidence from a natural experiment
}

Citation for published version (APA):

Montizaan, R. M., Cörvers, F., \& de Grip, A. (2009). The effects of pension rights and retirement age on training participation: evidence from a natural experiment. Researchcentrum voor Onderwijs en Arbeidsmarkt, Faculteit der Economische Wetenschappen. ROA Research Memoranda No. 12 https://doi.org/10.26481/umaror.2009012

Document status and date:

Published: 01/01/2009

DOI:

10.26481/umaror.2009012

Document Version:

Publisher's PDF, also known as Version of record

Please check the document version of this publication:

- A submitted manuscript is the version of the article upon submission and before peer-review. There can be important differences between the submitted version and the official published version of record.

People interested in the research are advised to contact the author for the final version of the publication, or visit the DOI to the publisher's website.

- The final author version and the galley proof are versions of the publication after peer review.

- The final published version features the final layout of the paper including the volume, issue and page numbers.

Link to publication

\footnotetext{
General rights rights.

- You may freely distribute the URL identifying the publication in the public portal. please follow below link for the End User Agreement:

www.umlib.nl/taverne-license

Take down policy

If you believe that this document breaches copyright please contact us at:

repository@maastrichtuniversity.nl

providing details and we will investigate your claim.
}

Copyright and moral rights for the publications made accessible in the public portal are retained by the authors and/or other copyright owners and it is a condition of accessing publications that users recognise and abide by the legal requirements associated with these

- Users may download and print one copy of any publication from the public portal for the purpose of private study or research.

- You may not further distribute the material or use it for any profit-making activity or commercial gain

If the publication is distributed under the terms of Article $25 \mathrm{fa}$ of the Dutch Copyright Act, indicated by the "Taverne" license above, 
Maastricht University

Research Centre for Education and the Labour Market | ROA

\section{The effects of pension rights and retirement age on training participation: Evidence from a natural experiment}

Raymond Montizaan

Frank Cörvers

Andries De Grip

\section{ROA Research Memorandum}

ROA-RM-2009/12

Research Centre for Education and the Labour Market Maastricht University

P.O. Box 616,6200 MD Maastricht, The Netherlands

$\mathrm{T}+31433883647 \mathrm{~F}+31433884914$

secretary-roa@maastrichtuniversity.n www.roa.nl 


\title{
The effects of pension rights and retirement age on training participation: Evidence from a natural experiment
}

\author{
Raymond Montizaan \\ Frank Cörvers \\ Andries De Grip
}

ROA-RM-2009/12*

September 2009

Research Centre for Education and the Labour Market Maastricht University P.O. Box 616, 6200 MD Maastricht, The Netherlands $\mathrm{T}+31433883647 \mathrm{~F}+31433884914$

secretary-roa@maastrichtuniversity.nl www.roa.nl

\footnotetext{
* The ROA Research Memorandum Series was created in order to make research results available for discussion, before those results are submitted for publication in journals.
} 


\section{Abstract \\ The effects of pension rights and retirement age on training participation: Evidence from a natural experiment**}

This paper uses a natural experiment approach to identify the effects of an exogenous change in future pension benefits on workers' training participation. We use unique matched survey and administrative data for male employees in the Dutch public sector who were born in 1949 or 1950 . Only the latter were subject to a major pension reform that diminished their pension rights. We find that this exogenous shock to pension rights postpones expected retirement and increases participation in training courses among older employees, although exclusively for those employed in large organizations.

Keywords: Natural experiment, retirement, training JEL codes: J14, J24, J26

Raymond Montizaan

ROA

Maastricht University

P.O. Box 616

6200 MD Maastricht

The Netherlands

r.montizaan@maastrichtuniversity

Andries de Grip

ROA

Maastricht University

P.O. Box 616

6200 MD Maastricht

The Netherlands

a.degrip@maastrichtuniversity.nl
Frank Cörvers

ROA

Maastricht University

P.O. Box 616

6200 MD Maastricht

The Netherlands

frank.corvers@maastrichtuniversity.nl

** We wish to thank Lex Borghans, Thomas Dohmen, Arnaud Dupuy, Bart Golsteyn and participants of SOLE, WPEG, IIPF and EALE for their useful comments on this article. We gratefully acknowledge ABP for making available the administrative data for this research. Any remaining shortcomings are the responsibility of the authors. 


\title{
The effects of pension rights and retirement age on training participation: Evidence from a natural experiment
}

\author{
Raymond Montizaan, Frank Cörvers and Andries De Grip \\ All three authors are employed at the Research Centre for Education and the Labour Market of \\ Maastricht University, Tongersestraat 53, Maastricht, Netherlands. Andries de Grip \\ is also affiliated with IZA, Bonn*
}

July, 2009

\begin{abstract}
This paper uses a natural experiment approach to identify the effects of an exogenous change in future pension benefits on workers' training participation. We use unique matched survey and administrative data for male employees in the Dutch public sector who were born in 1949 or 1950. Only the latter were subject to a major pension reform that diminished their pension rights. We find that this exogenous shock to pension rights postpones expected retirement and increases participation in training courses among older employees, although exclusively for those employed in large organizations.
\end{abstract}

Keywords: Natural experiment, retirement, training.

JEL codes: J14, J24, J26

\footnotetext{
*We wish to thank Lex Borghans, Thomas Dohmen, Arnaud Dupuy, Bart Golsteyn and participants of SOLE, WPEG, IIPF and EALE for their useful comments on this article. We gratefully acknowledge ABP for making available the administrative data for this research. Any remaining shortcomings are the responsibility of the authors. Correspondence: Raymond Montizaan, P.O. Box 616, NL 6200 MD, Maastricht University, Maastricht, Netherlands. E-mail: r.montizaan@maastrichtuniversity.nl. Tel: +31 43-3883801.
} 


\section{Introduction}

This study focuses on the impact of the abolishment of generous early retirement systems on training participation. Human capital theory predicts that early retirement systems have a negative effect on human capital formation. It is argued that the present value of net returns to human capital investments in older employees is lower due to the shorter period during which both employees and employers can reap the benefits of these investments (see Becker, 1975; Ben-Porath, 1967). ${ }^{1}$ Lau and Poutvaara (2006) integrated human capital investments and retirement decisions in a life cycle model and showed that generous social security systems induce early retirement and therefore have an indirect negative effect on human capital investments.

This paper exploits unique data on a natural experiment in the Dutch public sector to examine the impact of an exogenous increase in the expected retirement age on training participation. In 2006, the Dutch public sector was subject to a major pension reform that treated two very similar groups of employees differently. The reform consisted of the abolishment of pre-pension plans for everyone born after December 31, 1949. If employees were born before 1950 and have been working in the public sector continuously since April 1, 1997, they remained entitled to the older, more generous pre-pension rights. This means they can retire at the age of 62 years and 3 months with a pension at a replacement rate of $70 \%$. Employees born after 1949, however, are subject to the new, less generous pension system, which substantially lowers their pension benefits and creates incentives to postpone retirement. We expect that the increase in the expected retirement age induced training participation of workers in the treatment group. ${ }^{2}$ We also expect

\footnotetext{
${ }^{1}$ For employers, the benefits of investing in training of older workers take the form of retained or increased productivity. For older employees, training increases job satisfaction and can result in positive wage returns (Shields and Ward, 2001). An extensive literature estimates the wage returns of training investments. The general finding is that private returns are high, although studies that account for potential endogeneity, found much lower returns (Leuven and Oosterbeek, 2004; Leuven and Oosterbeek, 2008).

${ }^{2}$ Since the public sector's pension fund calculates the pension benefits on career-average wages rather
} 
that the postponement of retirement has different effects across organizations. Baron et al. (1987), Booth (1993), and Bassanini et al. (2005) showed that training propensity is much greater among larger organizations since offering training courses to employees incurs fixed costs that are generally paid by the employer. Since large organizations are more likely to employ a larger number of treated workers, the total benefit of extra training courses to this group will also be larger and therefore they are better capable to meet the fixed costs of the training provided. Moreover, it is generally found that larger organizations have more formally developed and sophisticated HRM policies than small organizations, which may increase their ability to adapt their personnel policies to labor market shocks (Koch and McGrath, 1996).

We use unique matched survey and administrative pension fund data for male employees in the public sector. The data were gathered one year after the introduction of the new pension system and incorporate detailed information on older employees' individual pension rights, expected sources of income after retirement, and training participation. We compare the training participation of employees born just before the treatment threshold (i.e., born in 1949) and who remain entitled to their old, generous pension rights, with that of those employees born just after the break (i.e., born in 1950) and therefore subject to the new pension system. We run separate analyses for individuals employed in large and large organizations.

We provide robust evidence that the postponement of retirement due to the sudden change in pension rights has a positive impact on the training participation of older workers, although exclusively in larger organizations. This indicates that larger organizations are better capable to customize their training policies to the new situation than smaller organizations. Furthermore, workers in the treatment group participate more often in long

than on the salary earned before retirement, the drop in the replacement rate hardly influences the pension wealth associated with the value of new human capital investments when workers in the treatment group decide at the end of their career not to postpone retirement. 
training courses. Finally, the treatment effect appears to be greater among less-educated workers.

This paper builds on previous studies that empirically analyzed the relation between early retirement and training investments. Fouarge and Schils (2008) and Bassanini et al. (2005) investigated the relation between the generosity and flexibility of pension systems and the training participation of older workers across different European countries. Both studies found that the training participation of older workers is lower in countries with more generous early pension systems. Since there exists a negative relation between pension plan generosity and early retirement age, both studies indirectly provide evidence of a causal relation. However, neither study rule out reverse causality (i.e., the effect of training participation on the retirement age). For example, when older workers participate in a training course, they and their employer might consider postponing retirement in order to further reap the benefits of their investment.

Other empirical studies have focused on related questions. Most of these analyzed the relation between age and training participation and found that training incidence decreases with age (e.g., De Grip en Van Loo, 2002; Bassanini et al., 2005). Several studies also analyzed the effects of shocks to life expectancy on human capital investments (Kalemli-Ozcan et al., 2000; Jayachandran and Lleras-Muney, 2008). These studies found that a drop in mortality rates, which increases the potential period during which investment benefits can be reaped, induces investments in human capital.

We contribute to the existing literature in two ways. First, the limited age difference between the treatment and control groups in our sample and the simple and transparent age criterion guaranties the internal validity of the experiment and substantiates the causal direction. Our findings are therefore less likely to be confounded than the earlier studies by Fouarge and Schils (2009) and Bassanini et al. (2005). Second, this paper explicitly analyzes the effects of early retirement incentives and how changing retirement 
expectations can affect training participation, whereas the extant literature on relation between (expected) life expectancy and human capital development provides only indirect evidence of this relation.

This paper is organized as follows. Section 2 discusses the exogenous shock to the Dutch public sector's pension system. Section 3 presents our estimation strategy. Section 4 describes the data and the final sample selection. Our results are presented in Section 5 and, Section 6 presents our conclusions.

\section{Reform of the Dutch public sector's pension sys- \\ tem}

\section{A. The Dutch pension system}

The Dutch pension system consists of three tiers: 1) a public old age pension that is paid to all inhabitants aged 65 years and and older, 2) a supplementary sectoral (or firm) pension, and 3) voluntary private pension plans. The public old age pension system is a "pay-asyou-go' system, in which current payments are financed by income taxes. Supplementary sectoral or firm pensions are defined benefit plans and very wide-spread since participation in these plans is mandatory. Public sector pension benefits are based on career-average wages rather than final salaries. Private insurance companies offer additional voluntary pension plans that typically take the form of savings plans that yield annuity payments at retirement. Due to extensive provision of supplementary pensions in the second tier, the third tier is less well developed in the Netherlands.

For almost all employees, retirement before the age of 65 is only possible through the sectoral pension systems in the second pillar. These early retirement plans are negotiated between unions and employer organizations at the sectoral or firm level and are officially 
laid down in collective agreements. In the public sector, both employers and employees contribute to the pension fund.

\section{B. Changes in the pension system for public sector employees}

Until 2006, early retirement plans were facilitated by the government through preferential tax treatment. This favorable tax treatment created a substantial advantage due to the progressive tax system (Euwals et al., 2006). ${ }^{3}$ In 2006, a reform in the Dutch pension system took place that provides the basis of our natural experiment. In line with its policy to stimulate the labor force participation of older employees, the government abolished the favorable tax treatment of early retirement plans for all employees born in 1950 or later. ${ }^{4}$ Employees born before 1950 and who worked continuously in the public sector since April 1, 1997, remain entitled to the generous old pre-pension rights. These old pension rights enable a typical employee who had worked for 40 years in the public sector to retire at the age of 62 years and 3 months at a replacement rate of $70 \% .^{5}$

In response to the abolishment of the tax treatment on January 1, 2006, the pension fund of the Dutch public sector (ABP) dramatically changed its pension plan (now called 'ABP flexible pension plan') for workers born in 1950 or later and for those who had not been working continuously in the public sector for the past 10 years. The new pension system is characterized by a drop in pension benefits when workers retire early, an increase in pension contribution payments to partially account for this drop in pension benefits and stronger incentives to continue working exemplified by penalties on pension income for retiring before the state pension commencement date and supplements for retiring

\footnotetext{
${ }^{3}$ Employees were allowed to deduct their share of the contribution to sectoral early retirement plans from their gross wages.

${ }^{4}$ This policy change was not limited to the public sector but also applied to employees in other sectors. However, the subsequent change in the pension system for the public sector were much larger than for other sectors.

${ }^{5}$ Traditionally, employees retire in the Netherlands having achieved a minimum replacement rate of $70 \%$.
} 
later. $^{6}$

For younger employees, the increase in pension contributions partly makes up for the decrease in pension wealth over time. ${ }^{7}$ Unlike young workers, however, public sector employees born just after 1949 do not have enough time to counter this drop in pension wealth if they wish to retire early. Therefore, due to both the abolishment of the tax rules and the steeper early retirement plan, these employees face a substantial decrease in pension wealth and will have to retire at a later age to reach a replacement rate of $70 \%$. The average employee born in 1950 who retires after having worked for 40 years in the public sector will have a replacement rate of $64 \%$ when he or she is 62 years and 3 months old or will have to postpone retirement until the age of 63 years and 4 months to reach a replacement rate of $70 \%$.

\section{Awareness of the exogenous shock in pension wealth}

For identification of our natural experiment, public sector employees must be aware of the consequences of the new pension system for their individual situation. To make the introduction of the new pension system known to their customers, ABP launched a campaign in the second half of 2005 to explain its implications. A special newspaper was devoted to the new pension system in which unions, employer organizations, and ABP jointly explained the new flexible pension plan. All 1.2 million ABP participants received a letter explaining the core elements of the new plan and a complete electronic service pack for public service employers was been developed. Therefore, on January 1, 2006, most public sector employees born after 1949 and their employers were familiar with the exogenous shock to their pension rights. Employees could react to the change by postponing their retirement, increasing investments in their human capital, or increasing

\footnotetext{
${ }^{6}$ Moreover, employees can decide to work until their 70 th birthday and can either retire fully or partially.

${ }^{7}$ However, since the new pension system is actuarially fair, employees born after 1949 are motivated to postpone retirement.
} 
their individual private (pension) savings.

\section{Exogenous shock in pension wealth and training incentives}

It is expected that employees in the treatment group have greater incentives to invest in their human capital compared with those in the control group. Using 'European Community Household Panel Data', Bassanini et al. (2005) found that private returns on training are approximately $3.7 \%$ in the Netherlands. We use this percentage to calculate returns measured in wages and pension income on a training investment in 2006 for both the treatment and control group. Assuming a discount rate of $3 \%$ and a life expectancy of 78 years, compared with the control group, employees born in 1950 have an extra return due to the expected postponement of their retirement of approximately 2,400 euro. For employees born in 1950 the total return on training until their death will about 21,400 euro whereas employees born in 1949 have a return of $19,000 .^{8}$

\section{Empirical strategy}

We make use of a natural experiment to identify the causal effect of the abolishment of the early retirement plan on human capital investments.

In our application, assignment of pension rights depends deterministically on the birth date $\left(b_{i}\right)$ of public worker $i$. The assignment rule is discontinuous and has the form

$$
D_{i}= \begin{cases}1 & \text { if } b_{i} \geq \bar{b}:=1 \text { January } 1950 \\ 0 & \text { otherwise }\end{cases}
$$

\footnotetext{
${ }^{8}$ The negative effect of the reduction in replacement rates on the return on training investments after retirement in 2006 is negligible because of two reasons: 1) Pension benefits are based on career-average wages rather than the final salary before retirement, implying that returns on additional investments for this group affect primarily wages over the remaining career and only marginally affect pension benefits after retirement; 2) There will only be a drop in replacement rates if workers in the treatment group decide not to postpone retirement. However, most workers delay retirement in order to achieve the expected replacement rate they had before the change.
} 
where $D_{i}$ is the assignment indicator. The probability of receiving training can be stated as

$$
E\left(T_{i}\right)=F\left(\alpha+\beta D_{i}\right)
$$

where $\alpha=E\left(T_{0 i}\right)$ is the training probability without an exogenous change in pension rights and $\beta=E\left(T_{1 i}\right)-E\left(T_{0 i}\right)$ is the difference in training probability caused by the treatment effect. There is no indication that persons close to $\bar{b}$ are subject to discontinuities other than the difference in pension rights. Therefore, comparing the training investment behavior of employees who were born in 1949 and remain entitled to their old, generous pension rights with that for employees born in 1950 and subject to the new pension system will provide unbiased estimates of the treatment effect (see Hahn et al. (2001) for a discussion of regularity conditions at the selection threshold):

$$
\beta=T^{+}-T^{-},
$$

where $T^{+}=\lim _{b \downarrow \bar{b}} E(T \mid b)$ and $T^{-}=\lim _{b \uparrow \bar{b}} E(T \mid b)$. We estimate the treatment effect with regression models of the form

$$
T_{i}=\alpha+\beta D_{i}+\eta P_{i}+\theta Y_{i}+\tau M_{i}+\zeta X_{i}+\epsilon_{i}
$$

where $T_{i}$ represents the training participation of worker $i$ and $D_{i}$ is the treatment dummy variable, which is 0 if the employee was born in 1949 or 1 if born in 1950 . We 
control for the number of years employees have built up their pension $P_{i}$. The variable $Y_{i}$ is the yearly wage income, $M_{i}$ stands for marital status, and $\epsilon_{i}$ is a random error. We also include some additional control variables $\left(X_{i}\right)$. Among others, we control for the presence of extra pension savings since 2006, the presence of 11 alternative pension income sources, level of education attained and employee sub-sector. The alternative pension income sources cover most of the potential retirement income sources in the third tier of the pension system.

\section{Data}

\section{A. Matched survey and administrative data and comparison groups}

We use detailed matched survey data and administrative data for male employees in the public sector. The date were collected in two stages one year after the introduction of the new pension system. ${ }^{9}$ In the first stage, all 27,871 male public sector employees born in 1949 or 1950 were sent a request to participate in the study and to give their e-mail address. In the second stage, in March, 2007, the employees who gave their permission, were sent an e-mail with a link to the survey. The survey asked detailed questions on the expected retirement age, training participation and expected sources of income after retirement other than the pension benefits provided by the public sector's pension fund. In total, 8,526 individuals started answering the questionnaire, 7,739 of whom successfully completed it. ${ }^{10}$

\footnotetext{
${ }^{9}$ The focus on male employees is due to the fact that in the Netherlands, in general, male employees aged 56 or 57 years are the main wage earner while female workers in the same birth cohort often have disrupted careers. In this age range, on average, men have contributed 28 years to the pension fund whereas women have contributed on average for only 16 years. Moreover, only a small select group of these women is still working. In the public sector, only 30\% of all employees born between 1940 and 1950 are women and, $72 \%$ of these work in a flexible or part-time job (Statistics Netherlands, 2005).

${ }^{10}$ The likelihood of selectivity bias due to use of Internet is negligible because $91 \%$ of public sector employees aged 55 years or older have Internet connection at home (TNS Nipo, 2006). Moreover, a large number of respondents filled out their questionnaires at work.
} 
The survey data are matched to administrative data of the pension fund that provides information on individual pension rights built up at ABP, annual wages, tenure in the public sector, size of the organization where employed, and the number of working hours.

We restrict the analysis to employees who have worked continuously for at least 10 years in the public sector because employees born before 1950 who did not work continuously in the public sector during the last 10 years are also subject to the new pension system. This restriction was made to avoid complications concerning unobserved characteristics of workers than can simultaneously affect training participation and eligibility for pension rights. Unobserved characteristics that influence the decision to work can affect whether a person is in the treatment or control group and the training decision. Moreover, workers who changed jobs in the last 10 years within the public sector and had a short career break might train more because they are working in a relatively new job. Estimates of the treatment effect on the training behavior of persons with career disruptions can therefore be upward biased. Focusing on those employees without a disrupted career ensures the validity of the experiment. ${ }^{11}$

Furthermore, we exclude employees who are employed in the military and some other specific occupations such as fireman or ambulance nurse because they are entitled to other early retirement arrangements, which also changed since January 1, 2006, and therefore might disturb the treatment effect of introducing the new pension system. The final sample consists of 7,019 men, 3,692 of whom were born in 1950 and form the treatment group and 3,327 of whom were born in 1949 and belong to the control group.

\section{B. Descriptive Statistics}

To uphold the validity of the natural experiment, it is essential for the employees in the

\footnotetext{
${ }^{11}$ However, we perform an additional robustness analysis on a sample of workers born in 1949, including those with a disrupted career. The results show that workers with reduced pension rights train significantly more than those in the same age cohort who are still entitled to the old pension rights (the coefficient of the treatment dummy is 0.133 , with a standard error of 0.065 ).
} 
treatment and control group to have the same characteristics except for the deviation in pension rights. Descriptive statistics for the whole sample, the treatment group and the control group are presented in Table 1 . Table 1 shows that the differences between the treatment and control group are indeed extremely small. There is no difference in organization size, marital status, or whether the partner has an income. Moreover, the individuals in both groups have similar levels of education and are equally distributed over sub sectors and birth months. The number of years individuals built up pension rights with the public sector's pension fund and the annual wage income are slightly higher for the control group. However, this reflects the limited age difference between the control and the treatment group. Table 1 also shows that approximately $23 \%$ of all employees in our sample increased their pension savings since 2006. As can be expected, the additional savings level is slightly higher for the treatment group.

\section{Exploratory analysis}

Table 1 provides an exploratory analysis of the changes in retirement expectations and the treatment effect on training participation. Retirement expectations are measured by two open survey questions: 1) 'At what age do you expect to retire?' 2) 'Suppose, you were to retire at the age of 62 . How large would your pension benefit be as a percentage of your net wage income?' Table 1 shows that the decrease in pension rights due to the pension system reform has increased the expected retirement age. Employees who were born in 1949 expect, on average, to retire at the age of 62 years and 6 months whereas employees born in 1950 anticipate to retire when they are 63 years and 4 months old. For both groups, these mean expected retirement ages corresponds closely to a replacement rate of $70 \%$. This implies that the treated workers will continue working until their pension benefits are restored at the level before the treatment. ${ }^{12}$ Moreover, Table 1 shows that the

\footnotetext{
${ }^{12}$ While approximately $80 \%$ of all workers in the Netherlands who retired under the old pre-pension rules in 2004 chose early retirement at the age of 62 years or younger (Statistics Netherlands, 2009), more
} 
expected replacement rate at the age of 62 years is $72.0 \%$ for the control group and only $66.2 \%$ for the treatment group. The fact that these replacement rates are only $2 \%$-points above the actual benefit they will receive, indicates that workers have fairly accurate retirement expectations.

Figure 1 and 2 present scatters plots of the differences in the mean expected retirement age and mean expected pension benefits at the age of 62 for all the birth months of the respondents. They show that the deviations between the treatment and control group emerge precisely around January 1, 1950, threshold. Therefore, it seems reasonable to conclude that employees are indeed familiar with the consequences of the new pension system for their individual situations.

We use two training variables in our analyses; one to measure the incidence of training and one to measure the number of hours spent on training courses in 2006. The variables are based on the following survey questions: 1) 'Did you undergo training or take a course in 2006 that was relevant to your job?' 2) 'How many hours did you spend in total in training courses in 2006?' Besides these two variables, we also asked workers to indicate retrospectively whether they participated in training or took a course in 2005. Table 1 shows that the training incidence in 2006 is about 3\%-point higher in the treatment group, although they train on average only one hour more than those in the control group. We also note that there was no difference in training participation in 2005 (before the treatment) between the treatment and control group and that training participation increased for both groups in 2006. However, the treatment group's training incidence increased with $7 \%$ points compared to only $4 \%$ points for the control group. This indicates that the exogenous shock to pension rights affected human capital investments. ${ }^{13}$

The high incidence of training found for the treatment group as well as the control than $70 \%$ of the treated workers in our sample expects to retire at 63 years or older.

${ }^{13} \mathrm{It}$ is worth noting that employers in the public sector strongly drive these human capital investments. In our sample, $97 \%$ of all training courses were paid for by the employer. Moreover, in $60 \%$ of all cases, the employer, or the employer and the employee together took the initiative for to participate in training. 
group corresponds closely to the level of training participation for the public sector in the OSA Labour Supply Panel, a representative panel survey of the Dutch working population. ${ }^{14}$

\section{Estimation results}

\section{A. Expected time to retirement, treatment and training participation}

We first estimate the effect of the expected time to retirement on training participation in 2006 without using the exogenous variation of the treatment dummy variable. We calculate the expected time to retirement by subtracting the age of the individual in 2006 from the expected retirement age. Column 1 of Table 2 reports the estimation results. We find a significant positive relation between the expected time to retirement and training participation. This suggests that postponing retirement by one year can lead to $1.4 \%$ higher training participation.

Concerning the control variables, we find that additional pension savings in 2006 are not significantly related to an employee's training participation. ${ }^{15}$ Also, the number of years in which pension contributions have been paid, and annual wages are not significantly related to training participation. Training participation of married workers is approximately $6 \%$ higher than that of workers who are not married. Also, workers with a higher level of education and those who work more hours participate more in training courses. Training participation of workers with a higher vocational education or an university background is between $17 \%$ and $28 \%$ higher than for those with lower levels of

\footnotetext{
${ }^{14}$ The OSA Labour Supply Panel also provides additional information on the type of training courses taken in the period 2000-2002. Although there is rich variation in the types of training courses attended, many public sector employees participated in information technology courses (19\% of all public sector employees), management courses $(13 \%)$ or administrative courses $(6 \%)$.

${ }^{15}$ We also estimated the model without control variables. We found that adding control variables does not affect the coefficient of the expected time to retirement.
} 
education.

Since the estimation in Column 1 does not exploit the exogenous policy shock, the previous results are subject to potential causality problems. The question is whether anticipation of early retirement affects training participation or whether training investments induce employees to postpone retirement. Therefore, we proceed by estimating the effects of the treatment dummy variable on training participation as described in Equation 4. The use of the treatment dummy enables us to assess the causal effect of the exogenous shock in the retirement expectations of public sector employees on their training participation. Column 2 of Table 2 shows that there is a positive treatment effect on training participation of about $2.7 \%{ }^{16}$ As the average expected retirement age between the two groups differs by 10 months, this corresponds to an increase in training participation of $3.2 \%$ when the working period until retirement is extended by one additional year. The coefficients of the other variables in our analysis do not differ much from those presented in Column 1.

The positive treatment effect is only marginally significant for the whole sample, which includes workers in both large and small organizations. As mentioned before, we expect the treatment effect to be stronger for workers in large organizations. Large organizations are more likely to employ a larger number of treated workers, which implies that they can more easily meet the fixed costs of training courses. Also, larger organizations have more formally developed and sophisticated HRM policies than small organizations (Koch and McGrath, 1996). Therefore, we continue by separately estimating the treatment effect for workers in organizations above or below the median organization size in our sample (the

\footnotetext{
${ }^{16}$ We also test whether our estimations are biased due to selectivity. It can be argued that more motivated employees were more prepared to respond to the questionnaire. For instance, employees born just one or two months after 1949 might not wish to cooperate because of their frustration over the change in the pension system. In that case, our previous estimations of the treatment effect would be biased. However, our results remain robust when estimating probit models accounting for sample selection on training participation following the approach of Van de Ven and Van Praag (1981). Moreover, we did not find any evidence of selection bias.
} 
median organization has approximately 1,000 employees). The results shown in Columns 3 and 4 of Table 2 confirm our expectations. We find a strongly significant treatment effect for workers of large organizations, while no significant effect is found for those who work in small or medium sized organizations. The difference in magnitude of the coefficients of the treatment variable is significant. For workers in large organizations, the training incidence in the treatment group is approximately $5.7 \%$ higher than in the control group. On the other hand, the treatment effect for workers in smaller organizations is approximately 0. Since, we only find a significant effect for workers in large organizations, our further analyses will exclusively focus on these workers. ${ }^{17}$

\section{B. Age and treatment effect}

It is well known that the probability of receiving training is a function of age. A relevant question is whether the difference in training propensities between the two birth cohorts goes beyond what would be expected based on the limited age difference alone. We approach this issue in the two estimations shown in Table $3 .{ }^{18}$ The estimations in Column 1 contains employee age as an additional variable. Since we know the exact birth date of all the workers in our sample, this variable measures age in days. With this correction for age, we find that the coefficient of the treatment dummy remains positive and highly significant.

However, some multicollinearity exists between the treatment dummy and the age variable that can confound the treatment effect. Another way to control for age effects is to compare the training incidence in 2005 of workers who were born in 1949 with the training incidence in 2006 of those born in 1950. By comparing the training incidence

\footnotetext{
${ }^{17}$ All further analyses were also performed on the sample of employees working in organizations below the median size. However, we did not find significant effects on the training participation of these workers.

${ }^{18}$ We also performed additional analyses where we reduced the age window around the treatment threshold. When we reduced the sample to those employees born close to the treatment threshold (three, six and nine months born around January 1, 1950), we found that the coefficient of the treatment dummy variable is slightly higher for workers born closer around the treatment threshold.
} 
at the same age for both groups of workers, there is no need to include the age variable and potential biases due to multicollinearity are avoided. Column 2 of Table 3 shows that the treatment effect in this additional robustness analysis remains robust. Again we find a positive coefficient that is significantly different from 0 and slightly higher than the coefficient shown in Column 3 of Table 2. The increase in the coefficient is less profound than when we include age directly in our estimations (see Column 1 of Table 3). ${ }^{19}$ Nevertheless, on the basis of the two previous estimations, we can conclude that the treatment variable indeed measures a treatment effect that goes beyond potential differences in the training propensities expected based on the age difference between the two birth cohorts.

\section{Skill groups and training participation}

Several recent empirical studies found that actual training participation depends on worker's motivation to train (e.g., Oosterbeek, 1998; Leuven and Oosterbeek, 1999; Croce and Tancioni, 2007) and that this motivation is highly correlated with the level of education (Maximiano and Oosterbeek, 2006). In general, more highly educated workers have a high training propensity due to their stronger motivation to invest in their human capital, irrespective of the duration of their remaining work life. On the other hand, we expect that the training behavior of less educated workers to be more affected by the treatment, since these workers who were initially less inclined to train are now forced to participate in training courses to keep up their productivity during their extended work life. We test this hypothesis by analyzing whether the pension reform has differentially affected the training behavior of workers with different levels of education. Column 1 of Table 4 shows the regression results for employees with a secondary or lesser education,

\footnotetext{
${ }^{19} \mathrm{~A}$ potential drawback of this analysis is that we are not able to account for potential business cycle effects. However, we expect that the probability that the business cycle confounds our estimation results is low. First, when considering business cycles, we can observe that the years 2005 and 2006 are similar. In both years, the Dutch economy experienced economic growth. Second, the OSA Labour Supply Panel shows that the incidence of training in the public sector remained stable between 2004 and 2006.
} 
Column 2 shows the results for those with an intermediate vocational education, and Column 3 for workers with a higher vocational education or a university degree. Table 4 shows that there are substantial differences in the impact of the retrenchment of pension wealth for the three skill groups. The treatment effect is much larger for workers who are less educated. ${ }^{20}$ This greater impact is consistent with the existing literature on training motivation and suggests that highly educated workers are indeed intrinsically more motivated to train, despite the sudden shock to their expected retirement age (Maximiano and Oosterbeek, 2006).

\section{Training participation: long or short courses}

One might expect the positive effects of a short training course on productivity to wear out in a short time period. If short courses only have short-term effects on productivity and the employees in our sample still have to work for approximately six or seven years until they retire, it is possible that participation in short courses has not yet been affected by the change in pension rights and expected time to retirement. Since about $50 \%$ of the employees who participated in training spent less than a full-time workweek of 40 hours in training courses, we perform additional analyzes for participation in long training courses and participation in training courses. We construct a dummy variable for participation in long training courses that is coded as 1 if employees trained more than 48 hours in 2006. The indicator for short training courses is coded as 1 if workers spent less than 48 hours on training in 2006. Table 5 shows that there exists a significant treatment effect on participation in long training courses while the impact of the pension reform on short training courses is insignificant. Workers in the treatment group participate approximately $7.3 \%$ more in long training courses than workers who were born in 1949 .

\footnotetext{
${ }^{20}$ Approximately $46 \%$ of the treated workers with a secondary or lesser education participated in a training course, $56 \%$ of those with an intermediate vocational education and $60 \%$ with a higher vocational education or a university degree.
} 


\section{Conclusions}

Human capital theory predicts that early retirement systems have a negative effect on human capital formation because early retirement reduces the period in which the benefits of training investments can be reaped. In this study, a natural experiment was used to identify the effects of an exogenous change in early pension rights on older employees' training participation. For this purpose, we used matched survey and administrative data for male employees in the Dutch public sector who were subject to a substantial pension reform in 2006. We compared employees who were born in 1949 and remain entitled to their old, generous pension rights with those born in 1950 and subject to the new system.

Using simple LPM regressions, we found that postponement of retirement due to the shock to pension rights has a positive impact on the training participation of older men. However, the treatment effect is only significant for workers in larger organizations. This suggests that larger organizations are better able to customize their training policies to the new retirement system with as possible explanation that they have more formally developed and sophisticated HRM policies than small organizations (Koch and McGrath, 1996).

We found that the treatment effect for workers in large organizations remains robust when we control for age and if we use alterative specifications. Furthermore, we found that the treatment effect is higher for lower educated workers. Moreover, as expected, the treatment effect was only significant for participation in longer training courses.

This paper focused on those employed in the public sector because the pension change was more profound in this sector. Moreover, it should be noted that the public sector in most European countries is the largest employer (Pilichowski and Turkisch, 2008). However, we are confident that our results do also apply to large organizations in the 
private sector because there has been substantial convergence in the employee conditions of public and private sector workers in the Netherlands. This implies that the status of public sector workers in 2006 resembled that of private sector workers (CAOP, 2006).

Most European countries face an ageing working population and are adapting retirement systems to stimulate the labor market participation of older workers by postponing retirement, either by increasing the retirement age directly or by reducing the generosity of pension benefits. These reforms are not restricted to national retirement plans but do also apply to the retirement schemes of public sector workers (see Palacios and Whitehouse (2006) for an overview of recent reforms to public sector pension plans in European countries).

In this context, our results are relevant since success in prolonging employment will highly depend on policies preventing skills obsolescence to maintain the productivity of older employees (see also De Grip and Van Loo, 2002). Our estimates indicate that, consistent with human capital theory, older employees who are forced to work longer increase their training participation and hence will increase their productivity and remain attractive to their employers. However, this only holds for those employed in large organizations. Older workers employed in small organizations seem to be more restrained in their human capital investments when public policy restricts the opportunities of early retirement and therefore probably have more problems remaining productively employed for a longer period.

\section{References}

Baron, J., Black, D., Loewenstein, M., 1987. Employer size: The implications for search, training, capital investment, starting wages, and wage growth. Journal of Labor Economics 5, 76-89. 
Bassanini, A., Booth, A., Brunello, G., de Paola, M., Leuven, E., 2005. Workplace training in Europe. IZA Working paper 1640.

Becker, G. S., 1975. Human Capital, 2nd Edition. Chicago: University of Chicago Press.

Ben-Porath, Y., 1967. The production of human capital and the life cycle of earnings. Journal of Political Economy 75 (4), 352-365.

Booth, A. L., 1993. Private sector training and graduate earnings. Review of Economics and Statistics 75, 164-170.

CAOP, 2006. Advies van de raad voor het overheidspersoneelsbeleid: Normalisatie rechtspositie overheidspersoneel.

Croce, G., Tancioni, M., 2007. Disentangling factors behind training participation in Italy. Working paper.

De Grip, A., van Loo, J., 2002. The economics of skills obsolescence. Research in Labor Economics 21, 1-26.

Euwals, R. W., van Vuuren, D. J., Wolthoff, R. P., 2006. Early retirement behaviour in the Netherlands: Evidence from a policy reform. Tinbergen Institute Discussion Paper $2006-021 / 3$.

Fouarge, D., Schils, T., 2009. The effect of early retirement incentives on the training participation of older workers. Labour 23, 85-109.

Hahn, J., Todd, P., van der Klauw, W., 2001. Identification and estimation of treatment effects with a regression-discontinuity design. Econometrica 69 (3), 201-209.

Jayachandran, S., Lleras-Muney, A., 2008. Life expectancy and human capital investments: Evidence from maternal mortality declines. NBER Working paper W13947. 
Kalemli-Ozcan, S., Ryder, H., Weil, D., 2000. Mortality decline, human capital investment and economic growth. Journal of Development Economics 62, 1-23.

Koch, M., McGrath, R., 1996. Improving labor productivity: Human resource management policies do matter. Strategic Management Journal 17, 335-354.

Lau, M. I., Poutvaara, P., 2006. Social security investments and human capital investment. Finnish Economic Papers 19, 16-24.

Leuven, E., Oosterbeek, H., 1999. The demand and supply of work-related training: Evidence from four countries. Research in Labor Economics 18, 303-330.

Leuven, E., Oosterbeek, H., 2004. Evaluating the effects of a tax deduction on training. Journal of Labor Economics 22, 464-388.

Leuven, E., Oosterbeek, H., 2008. An alternative approach to estimate the wage returns to private-sector training. Journal of Applied Econometrics 23, 423-434.

Maximiano, S., Oosterbeek, H., 2006. On the determinants of workers' and firms' willingness to train. Working paper.

Oosterbeek, H., 1998. Unraveling supply and demand factors in work-related training. Oxford Economic Papers 50, 266-283.

Palacios, R., Whitehouse, E., 2006. Civil-service pension schemes around the world. SP Discussion paper No. 0602.

Pilichowski, E., Turkisch, E., 2008. Employment in government in the perspective of the production costs of goods and services in the public sector. OECD Working Papers on Public Governance, No. 8. 
Shields, M. A., Ward, M., 2001. Improving nurse retention in the national health service in england: The impact of job satisfaction on intentions to quit. Journal of Health Economics 20, 677-701.

Statistics Netherlands, 2005. Statline. Enquete Werkgelegenheid en Lonen (EWL) 19952005.

Statistics Netherlands, 2009. Statline. Labour Force Survey.

TNS Nipo, 2006. ABP marktmonitor 12-meting e5351, Amsterdam.

Van de Ven, W., Van Praag, B., 1981. The demand for deductibles in private health insurance: A probit model with sample selection. Journal of Econometrics 17, 229-352. 
Table 1

Descriptive statistics

\begin{tabular}{|c|c|c|c|}
\hline Variable Description & $\begin{array}{l}\text { Entire } \\
\text { sample }\end{array}$ & $\begin{array}{c}\text { Born } \\
\text { in } 1949\end{array}$ & $\begin{array}{c}\text { Born } \\
\text { in } 1950\end{array}$ \\
\hline \multicolumn{4}{|l|}{ Worker characteristics } \\
\hline \multirow[t]{2}{*}{ Number of years contributed to the pension fund } & 28.64 & 29.22 & 28.10 \\
\hline & $(8.68)$ & $(8.57)$ & $(8.75)$ \\
\hline \multirow[t]{2}{*}{ Extra pension savings since 2006 ( 1 if savings increased) } & 0.23 & 0.21 & 0.26 \\
\hline & $(0.42)$ & $(0.41)$ & $(0.44)$ \\
\hline \multirow[t]{2}{*}{ Yearly wage income (in euros) } & 48,620 & 48,835 & 48,419 \\
\hline & $(18,379)$ & $(18,485)$ & $(18,278)$ \\
\hline \multirow[t]{2}{*}{ Size of organization (number of employees) } & 5,236 & 5,332 & 5,199 \\
\hline & $(9,764)$ & $(9,850)$ & $(9,684)$ \\
\hline \multirow[t]{2}{*}{ Marital status } & 0.91 & 0.92 & 0.90 \\
\hline & $(0.29)$ & $(0.27)$ & $(0.30)$ \\
\hline \multirow[t]{2}{*}{ Primary or secondary education } & 0.18 & 0.19 & 0.17 \\
\hline & $(0.39)$ & $(0.38)$ & $(0.39)$ \\
\hline \multirow[t]{2}{*}{ Intermediate vocational education } & 0.15 & 0.15 & 0.15 \\
\hline & $(0.35)$ & $(0.35)$ & $(0.36)$ \\
\hline \multirow[t]{2}{*}{ Higher education or university degree } & 0.67 & 0.68 & 0.67 \\
\hline & $(0.47)$ & $(0.47)$ & $(0.47)$ \\
\hline \multirow[t]{2}{*}{ Income partner ( 1 if partner has own income ) } & 0.74 & 0.73 & 0.75 \\
\hline & $(0.44)$ & $(0.44)$ & $(0.43)$ \\
\hline \multicolumn{4}{|l|}{ Pension rights and training } \\
\hline \multirow[t]{2}{*}{ Expected retirement age (in years) } & 63.11 & 62.70 & 63.50 \\
\hline & $(1.75)$ & $(1.62)$ & $(1.78)$ \\
\hline \multirow[t]{2}{*}{ Expected retirement benefit at age of 62 (in $\%$ of net present wage) } & 68.94 & 72.02 & 66.18 \\
\hline & $(12.36)$ & $(11.95)$ & $(12.10)$ \\
\hline \multirow[t]{2}{*}{ Good overview of pension rights ( 1 if good overview) } & 0.59 & 0.64 & 0.56 \\
\hline & $(0.49)$ & $(0.48)$ & $(0.50)$ \\
\hline \multirow[t]{2}{*}{ Training participation in 2006 ( 1 if trained) } & 0.56 & 0.54 & 0.57 \\
\hline & $(0.50)$ & $(0.50)$ & $(0.50)$ \\
\hline \multirow[t]{2}{*}{ Training participation in 2005 ( 1 if trained) } & 0.50 & 0.50 & 0.50 \\
\hline & $(0.50)$ & $(0.50)$ & $(0.50)$ \\
\hline \multirow[t]{2}{*}{ Number of hours trained (if trained) } & 46.79 & 46.21 & 47.27 \\
\hline & $(36.84)$ & $(36.08)$ & $(37.47)$ \\
\hline Number of observations & 7,019 & 3,327 & 3,692 \\
\hline
\end{tabular}

Sample standard deviations are in parentheses below the sample averages. The number of pension years and the yearly wage income are extracted from administrative data of Dutch public sector's pension fund (ABP). The number of pension years indicates how many years individuals build up pension rights with the ABP. 
Table 2

Expected time to retirement, treatment and training participation in 2006

\begin{tabular}{|c|c|c|c|c|}
\hline \multirow[t]{3}{*}{ Dependent Variable: } & (1) & $(2)$ & $(3)$ & $(4)$ \\
\hline & LPM & LPM & LPM & LPM \\
\hline & Total & Total & Large & Small \\
\hline Training participation in 2006 & Sample & Sample & Organizations & Organizations \\
\hline \multirow[t]{2}{*}{ Expected time to retirement } & $0.013^{* * *}$ & & & \\
\hline & $(0.004)$ & & & \\
\hline \multirow[t]{2}{*}{ Treatment dummy } & & $0.027^{*}$ & $0.057^{* * *}$ & -0.005 \\
\hline & & $(0.015)$ & $(0.021)$ & $(0.020)$ \\
\hline \multirow[t]{2}{*}{ Number of years contributed to the pension fund } & 0.001 & 0.000 & -0.001 & -0.000 \\
\hline & $(0.001)$ & $(0.001)$ & $(0.002)$ & $(0.002)$ \\
\hline \multirow[t]{2}{*}{ Extra pension savings } & 0.018 & 0.017 & 0.039 & 0.002 \\
\hline & $(0.020)$ & $(0.020)$ & $(0.029)$ & $(0.027)$ \\
\hline \multirow[t]{2}{*}{ Yearly wage (divided by 10,000 ) } & 0.006 & 0.006 & 0.006 & 0.012 \\
\hline & $(0.006)$ & $(0.006)$ & $(0.008)$ & $(0.010)$ \\
\hline \multirow[t]{2}{*}{ Contractual work hours } & $0.398^{*}$ & $0.444^{* *}$ & 0.153 & $0.680^{* *}$ \\
\hline & $(0.222)$ & $(0.218)$ & $(0.312)$ & $(0.310)$ \\
\hline \multirow[t]{2}{*}{ Marital status } & $0.058^{* *}$ & $0.060^{* *}$ & $0.095^{* *}$ & 0.029 \\
\hline & $(0.026)$ & $(0.026)$ & $(0.037)$ & $(0.037)$ \\
\hline \multirow[t]{2}{*}{ Size of organization (divided by 10,000 ) } & -0.003 & -0.002 & 0.008 & $-0.680^{*}$ \\
\hline & $(0.011)$ & $(0.011)$ & $(0.012)$ & $(0.310)$ \\
\hline \multirow[t]{2}{*}{ Constant } & -0.249 & -0.190 & -0.031 & -0.180 \\
\hline & $(0.236)$ & $(0.232)$ & $(0.337)$ & $(0.339)$ \\
\hline Observations & 4,508 & 4,587 & 2,265 & 2,312 \\
\hline
\end{tabular}

Standard errors in parentheses.

*** $\mathrm{p}<0.01,{ }^{* *} \mathrm{p}<0.05,{ }^{*} \mathrm{p}<0.1$

The number of years contributed to the pension fund, the yearly wage and the size of the organization where employed are extracted from the administrative data of the Dutch public sector's pension fund (ABP). Other control variables included in the estimations are: educational levels, sub sector fixed effects and dummy variables indicating the presence of 11 other potential income sources after retirement. The most relevant alternative income sources are: another pension fund, a partner's income and savings. 
Table 3

Age effects, expected time to retirement and training in large organizations

\begin{tabular}{lll}
\hline \hline Variables & $\mathbf{( 1 )}$ & $\mathbf{( 2 )}$ \\
& LPM & LPM \\
& Training & Training \\
& $\mathbf{2 0 0 6}$ & $\mathbf{2 0 0 5} / \mathbf{2 0 0 6}$ \\
\hline Treatment dummy & $0.109^{* *}$ & $0.062^{* * *}$ \\
& $(0.043)$ & $(0.021)$ \\
Age (in days divided by 10,000) & -1.472 & \\
Number of years contributed to the pension fund & $(1.003)$ & \\
Extra pension savings & -0.002 & -0.003 \\
Yearly wage (divided by 10,000) & $(0.002)$ & $(0.002)$ \\
Contractual work hours & 0.029 & 0.018 \\
Marital status & $(0.029)$ & $(0.029)$ \\
Size of organization (divided by 10,000) & 0.008 & 0.012 \\
Constant & $(0.008)$ & $(0.008)$ \\
Observations & 0.250 & 0.493 \\
\hline \hline
\end{tabular}

Standard errors in parentheses

*** $\mathrm{p}<0.01,{ }^{* *} \mathrm{p}<0.05,{ }^{*} \mathrm{p}<0.1$

In Column 1, the dependent variable is training participation in 2006. The dependent variable in Column 2 measures the training incidence in 2005 of workers born in 1949 and the training incidence in 2006 of those born in 1950. Other control variables are: educational levels, sub sector fixed effects, and dummy variables indicating the presence of 11 other potential income sources after retirement. 
Table 4

Treatment effect on training participation in large organizations: Differences among skill groups

\begin{tabular}{llll}
\hline Dependent Variable: & $\mathbf{( 1 )}$ & $\mathbf{( 2 )}$ & $\mathbf{( 3 )}$ \\
Training participation in 2006 & $\begin{array}{l}\text { Primary or } \\
\text { Secondary }\end{array}$ & $\begin{array}{l}\text { Intermediate } \\
\text { Vocational }\end{array}$ & $\begin{array}{l}\text { Higher } \\
\text { Education }\end{array}$ \\
& $\begin{array}{l}\text { Education } \\
\text { Education }\end{array}$ & \\
\hline Treatment dummy & $0.197^{* *}$ & $0.191^{*}$ & 0.073 \\
Age (in days divided by 10,000) & $(0.090)$ & $(0.106)$ & $(0.054)$ \\
Number of years contributed to the pension fund & -0.004 & 3.638 & 1.089 \\
& $(0.004)$ & $(0.005)$ & $(1.259)$ \\
Extra pension savings & 0.070 & 0.047 & 0.001 \\
Yearly wage (divided by 10000) & $(0.073)$ & $(0.072)$ & 0.026 \\
Contractual work hours & $0.048^{*}$ & 0.046 & $0.0035)$ \\
Marital status & $(0.025)$ & $(0.036)$ & $(0.008)$ \\
Size of organization & 0.466 & 1.764 & 0.166 \\
Constant & $(0.956)$ & $(1.375)$ & $(0.341)$ \\
Observations & 0.073 & 0.084 & 0.076 \\
\hline \hline Standard ers & $(0.075)$ & $(0.088)$ & $(0.049)$ \\
& -0.018 & -0.022 & $0.030^{*}$ \\
& $(0.022)$ & $(0.031)$ & $(0.017)$ \\
& -0.956 & -2.671 & -0.268 \\
& $(1.242)$ & $(1.684)$ & $(0.594)$ \\
& 477 & 387 & 1,411 \\
\hline
\end{tabular}

Standard errors in parentheses

*** $\mathrm{p}<0.01, * * \mathrm{p}<0.05, * \mathrm{p}<0.1$

Column 1 presents the results for workers with a secondary education or less, Column 2 shows the results for workers with an intermediate vocational education, and Column 3 shows the results for workers with a higher vocational education or a university degree. Other included control variables are: educational levels, sub sector fixed effects and dummy variables indicating the presence of 11 other potential income sources after retirement. 
Table 5

Treatment effect in large organizations: short and long training courses

\begin{tabular}{|c|c|c|}
\hline Variables & $\begin{array}{c}(1) \\
\text { LPM } \\
\text { Large training } \\
\text { courses }\end{array}$ & $\begin{array}{c}(2) \\
\text { LPM } \\
\text { Small training } \\
\text { courses }\end{array}$ \\
\hline Treatment dummy & $\begin{array}{c}0.073^{* *} \\
(0.034)\end{array}$ & $\begin{array}{c}0.047 \\
(0.040)\end{array}$ \\
\hline Age (in days divided by 10,000 ) & $\begin{array}{c}0.561 \\
(0.792)\end{array}$ & $\begin{array}{c}1.046 \\
(0.928)\end{array}$ \\
\hline Number of years contributed to the pension fund & $\begin{array}{c}0.001 \\
(0.002)\end{array}$ & $\begin{array}{l}-0.002 \\
(0.002)\end{array}$ \\
\hline Extra pension savings & $\begin{array}{c}0.023 \\
(0.023)\end{array}$ & $\begin{array}{c}0.014 \\
(0.027)\end{array}$ \\
\hline Yearly wage (divided by 10,000) & $\begin{array}{c}0.007 \\
(0.007)\end{array}$ & $\begin{array}{l}-0.002 \\
(0.008)\end{array}$ \\
\hline Contractual work hours & $\begin{array}{c}0.600 * * \\
(0.249)\end{array}$ & $\begin{array}{l}-0.445 \\
(0.292)\end{array}$ \\
\hline Marital status & $\begin{array}{c}0.023 \\
(0.030)\end{array}$ & $\begin{array}{c}0.069^{* *} \\
(0.035)\end{array}$ \\
\hline Size of organization (divided by 10,000 ) & $\begin{array}{c}0.029 * * * \\
(0.010)\end{array}$ & $\begin{array}{c}-0.022 * \\
(0.011)\end{array}$ \\
\hline Constant & $\begin{array}{c}-0.938^{* *} \\
(0.407)\end{array}$ & $\begin{array}{c}0.254 \\
(0.477)\end{array}$ \\
\hline Observations & 2,265 & 2,265 \\
\hline
\end{tabular}

Standard errors in parentheses

*** $\mathrm{p}<0.01, * * \mathrm{p}<0.05, * \mathrm{p}<0.1$

The dependent variable in Columns 1 is coded 1 if employees spent more than 48 hours in training courses in 2006 and 0 otherwise. The dependent variable in Columns 2 is coded 1 when workers trained 48 hours or less and 0 otherwise. Other control variables are: educational levels, sub sector fixed effects and dummy variables indicating the presence of 11 other potential income sources after retirement. 
Figure 1

Expected retirement age

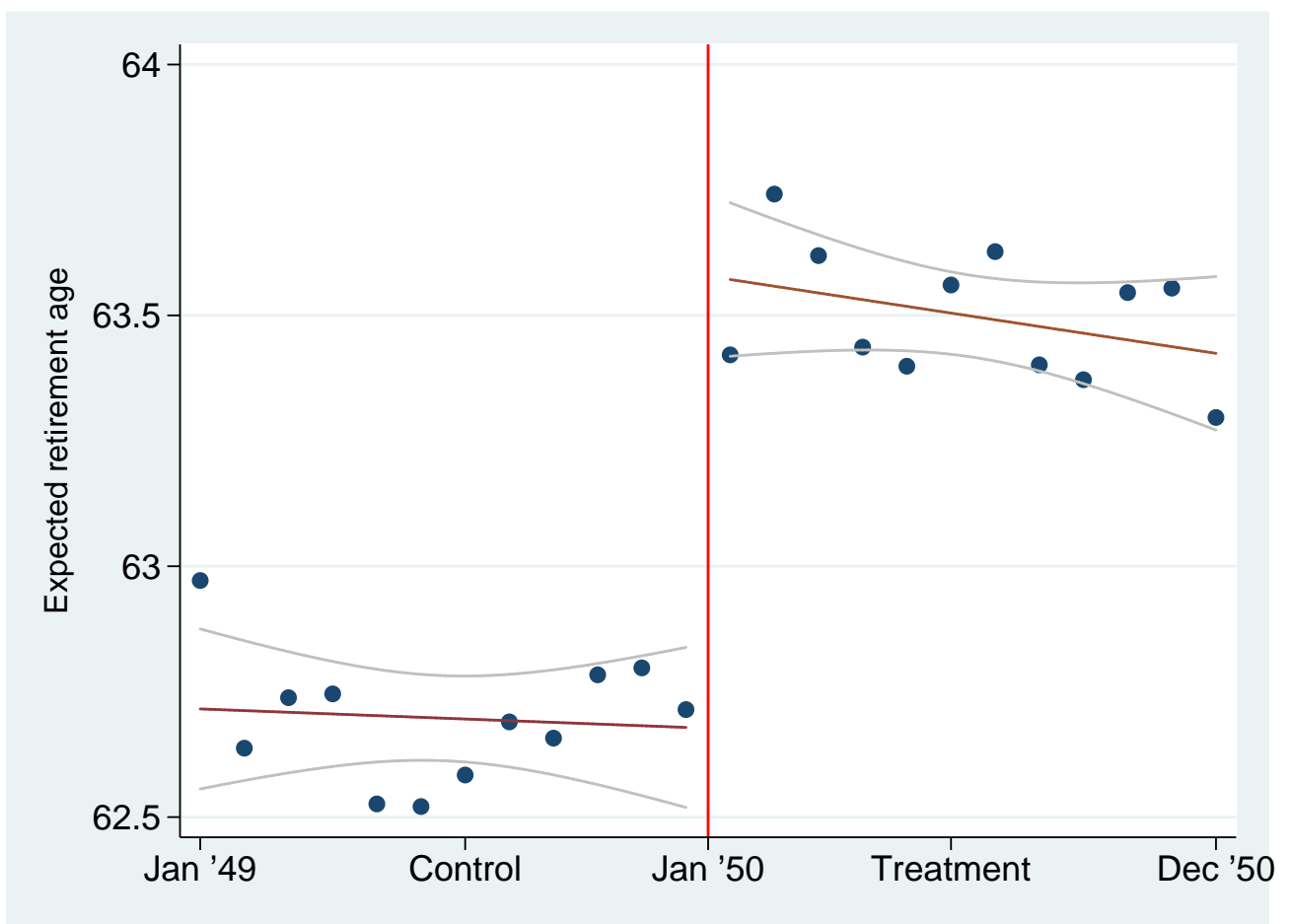

This figure presents the mean of the expected retirement age for each birth month from January 1949 to December 1950. Our sample consists of two birth year cohorts where employees born in 1949 are entitled to the old pension rules and employees born in 1950 are subject to the new pension rules. The vertical line marks the threshold which divides the control group from the treatment group. 
Figure 2

Expected pension benefit at age of 62 (in percentage of present net wage income)

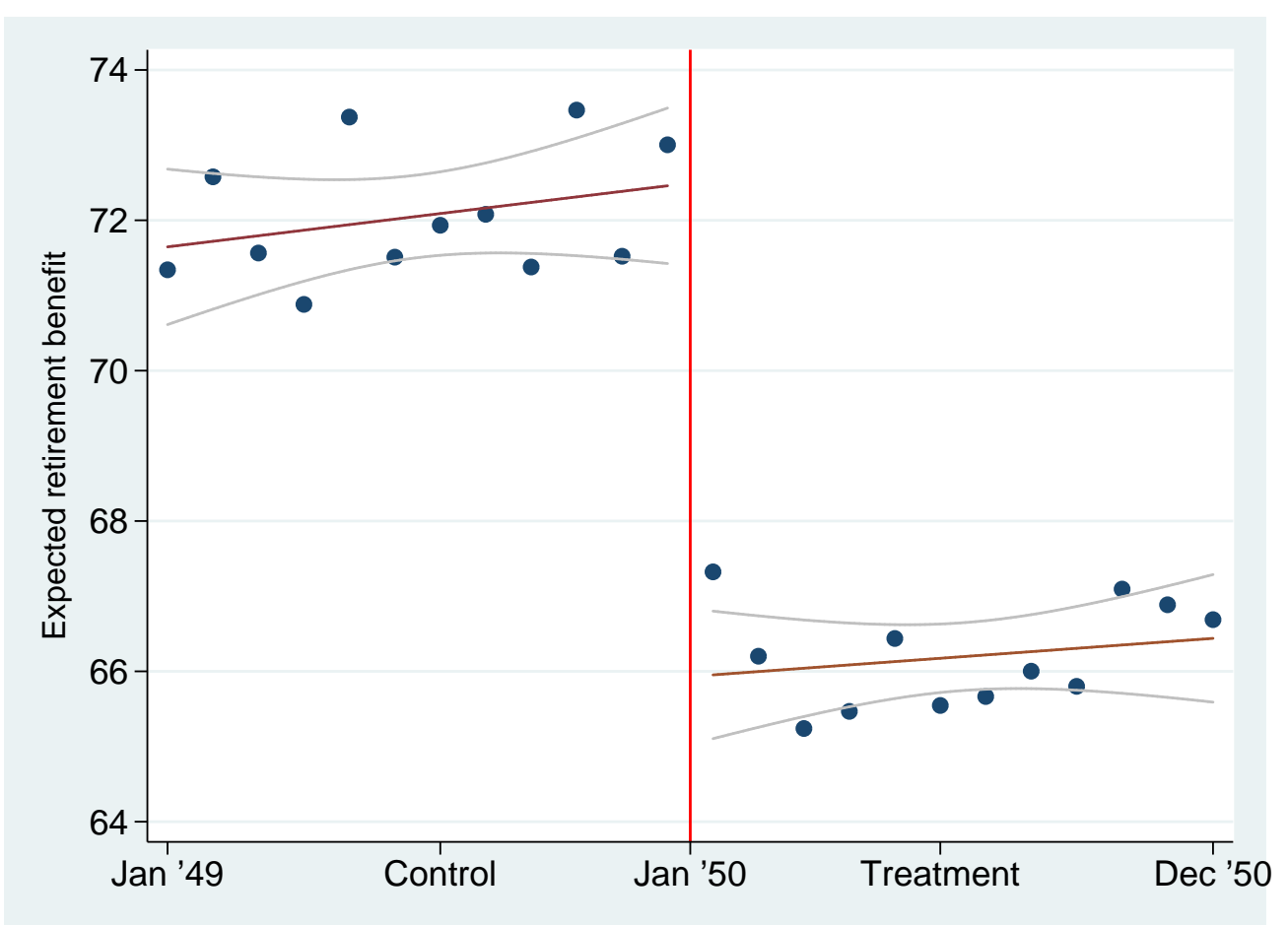

This figure presents the mean expected pension benefit at age 62 as a percentage of present wage income for each birth month. The information is based on the following survey question: Suppose you were to retire at the age of 62 . How large would your pension benefit be (as a percentage of your net wage income)? Our sample consists of two birth year cohorts where employees born in 1949 are entitled to the old pension rules and employees born in 1950 are subject to the new pension rules. The vertical line marks the threshold which divides the control group from the treatment group. 